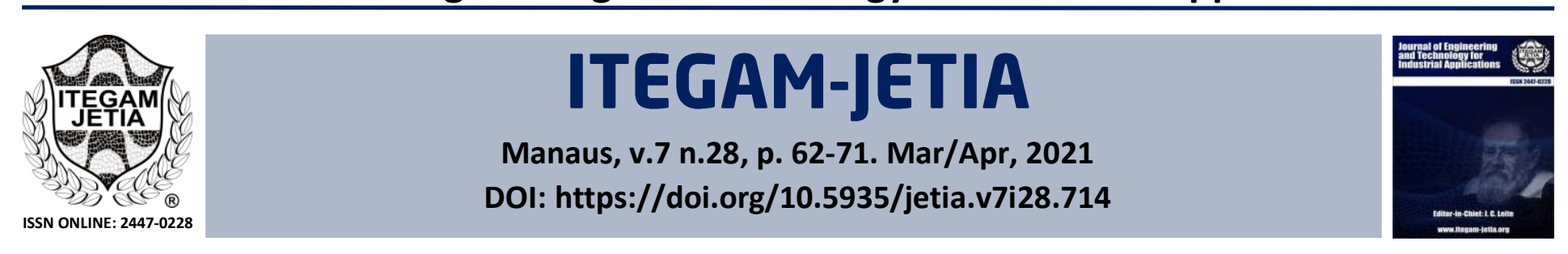

\title{
REFORESTATION AND RECOVERY OF DEGRADED AREAS OF THE TARUMÃ-AÇU WATERSHED AND ITS CONTRIBUTION TO REDUCING GREENHOUSE
}

\author{
Eliana da Conceição Rodrigues Veras*1 \\ ${ }^{1}$ Federal University of Pará. Belém, Pará, Brazil. \\ ${ }^{1}$ http://orcid.org/0000-0001-8703-653X (i) \\ Email: *elianaveras8@gmail.com
}

\begin{tabular}{l} 
ARTICLE INFO \\
\hline Article History \\
Received: October $27^{\text {th }}, 2020$ \\
Accepted: March $29^{\text {th }}, 2021$ \\
Published: April $30^{\text {th }}, 2021$
\end{tabular}

Keywords:

Reforestation,

Degraded Area,

Carbon Absorption,

Greenhouse Effect.

\begin{abstract}
Here we present the results of the reforestation project in degraded areas of the Tarumá-Açu Watershed and the estimation of the $\mathrm{CO}$ fixation for the reduction of greenhouse gas emissions during the 20-year period. For each species analyzed after planting, during the period 2015-2019, the method used was participatory observation, where those involved analyzed the data in loco, recording, through photos, the development of seedlings in terms of growth, mortality and survival in order to replace the dead with others that could carry out the functions of environmental protection and minimize the degradation process of the area. It can be said that the management of the process was necessary due to the climatic changes that occur during the year, since the monitoring of the species occurred in March, the rainy season and August, the summer season, or different periods: complete and dry. The observation was part of the whole process, from the moment of requesting the seedlings to replace the dead ones, analyzing those that have a higher survival rate and those that need a closer monitoring, due to the mortality rate. The growth, mortality and survival rates of the species are highly variable. Each species has different characteristics, therefore, the data found present different percentages for species planted in the same area, either lowlands or igapó. In 5 years of topography of the species and data, it can be said that the plants gradually adapt to the adversities of the soil and climate. Planting seedlings in the field should preferably be carried out after 30 days of preparation of the pits. The planting procedure is the same as described above, needing to remove the package containing the seedling and only then insert it into the well. The pit is then closed with the soil pressing it, so that there is more contact between the seedling substrate and the soil. As a result of the first step of the experimental methodology, with the participation of the community, students and volunteers, a brochure on how to care for the environment was distributed free of charge, illustrated by the Amazonian fauna, existing in the area, in schools and the community, at the end of each conference on environmental education.
\end{abstract}

\section{INTRODUCTION}

The Tarumã-Açu-BHT Hydrographic Basin is located on the west side of the municipality of Manaus. Since the 1950s, it has been occupied by farmers and later by extractivists, with a great urban expansion, generating real estate speculation in the area. The high demand for occupancy by the middle and upper classes led to the creation of marinas, condominiums and second homes, for use on weekends. Over time, the occupation by commercial establishments, the so-called floating ones, occupied the entire hydrographic basin. These occupations and the disorderly removal of boulders and sand from the site, have caused soil degradation and deforestation in the area, which has led us to develop environmental education and reforestation practices in the basin, in order to minimize the impacts. generated. 
In order for us to achieve the proposed objectives, it was necessary to sensitize the surrounding community through Environmental Education, initially in schools with children, considering the rest of the community members so that everyone could know the importance of the Basin and the need to conserve it for the future generations.

Environmental education is a continuous process in the development of research and species monitoring. There are talks, group activities, correct disposal of waste and finally, everyone plants a tree seedling.

As a result of the dissemination of environmental education in the community, it is possible to create a children's magazine, with images of the local fauna and flora, in a simple and objective language, oriented towards the protection of the forest and rivers.

The recovery and reforestation area is part of the Tarumã Açu - Tarumã Mirim Settlements, part of the Tarumã-açu Hydrographic Basin, located on the left bank of the Negro River, it has 56,793ha, it is located between parallels $2^{\circ} 41$ ' 44 "and $3^{\circ}$ 03'37" South Latitude and meridians $60^{\circ} 03^{\prime} 41^{\prime \prime}$ and $60^{\circ} 18^{\prime} 27$ "West Longitude, in the municipality of Manaus - State of Amazonas.

The Tarumã-Açu River Basin (BHT), located in the north and west of the Manaus municipality, is considered one of the main waterways of the Tarumã-Açu River. It is a tributary of the Río Negro on the left bank, it is located very close to the urban perimeter of the city of Manaus. Access to the Tarumã basin can be through secondary roads, branches and rivers.

In the research development area, it has rainfed, shallow, campinarana and campina vegetation, as well as epiphytes such as bromeliads and orchids - Bryophytes, Orchids and Bromeliads.

Through research in books and articles on the subject, we found several works developed in the basin, however mostly focused on the sustainability of water resources, without finding any specific on reforestation and recovery of the degraded area. However, we propose to develop the research, taking into account the need to recover and reforest an extensive degraded area, which effectively causes an environmental impact on the site.

For this, we rely on the traditional indigenous and local population in the planning and development of the recovery plan for the degraded area. - PRAD, in addition to professional volunteers. Thus, we hope to contribute to the development of other research works, in order to preserve and conserve the Tarumã Basin.

\section{THEORETICAL FOUNDATION}

\section{II.1 ENVIRONMENTAL MANAGEMENT}

For [1], the more general definition of environmental management suggests that it is a set of actions that involve public policies, the productive sector and society in order to encourage the rational and sustainable use of environmental resources. It is, therefore, a process that links conservation and development issues at all levels.

An efficient environmental management system, according to [2], needs to articulate different areas of the organization, with emphasis on the marketing, production, human resources, legal and financial, research and development sectors.

For [3], both the command and control mechanisms by the State and those of environmental competition between companies play a decisive role in advancing environmental management strategies in operations, especially in economies such as Brazil, in the that is required to advance. In terms of universalization of socio-environmental rights.

\section{II.2 DEGRADED AREA}

According to Federal Decree 97.632/89, the concept of degraded area or degraded landscapes can be understood as places where there are (or have been) processes that cause damage to the environment, by which some of its properties are lost or diminished, such as quality productive of natural resources.

For [4], considers that the structural problems associated with harmful forms of urbanization have had a strong influence on environmental deterioration, in its broadest sense, ranging from the degradation of natural resources to deeper social problems, such as own homelessness. and its location in areas far from the urban fabric, in contrast to the existence of empty plots in urbanized regions, having as one of its causes the little effectiveness of social policies for access to land and housing.

For [5], environmental degradation is a consequence of activities that directly or indirectly damage the health, safety and well-being of the population; create adverse conditions for social and economic activities; adversely affect biotic factors; Affect the aesthetic or sanitary conditions of the Environment and release materials or energy that do not comply with the established environmental standards.

\section{II.3 REFORESTATION AND RECOVERY OF THE DEGRADED AREA}

Degradation of an area occurs when native vegetation and fauna are destroyed, removed, or driven out; the fertile soil layer is lost, removed or buried; and the quality and flow regime of the water system are modified. If there is a loss of adaptation to physical, chemical and biological characteristics and socioeconomic development, it is not feasible [6].

Many heterogeneous reforestation projects with native species have failed due to scarce technical knowledge, mainly about the biology of the species used, or their behavior in artificial reforestation. The lack of scientific criteria to understand the behavior of the dynamics of natural forests (the process by which species regenerate and develop after the natural fall of trees, with clearing formations that are then occupied by new individuals of different species), or technologies to collect seeds, process and produce seedlings, are other factors that influenced the process of forest restoration [7].

Says that the reforestation of degraded areas with native species is an important alternative for environmental recovery. In reforesting degraded environments, it is important to select species that are better able to settle and grow in poor soil conditions [8].

Clarifies that native legumes occupy a prominent place in each and every one of the ecologically prepared reforestation processes, since they are plants that fix atmospheric nitrogen in the soil, enriching it and making it suitable for agricultural cultivation [9].

\section{II.4 WESTERN ANACARDIUM}

The cashew is considered a native plant of Brazil. When the colonizers arrived here, they found it very widespread on the northeast coast, composing the vegetation of beaches, dunes and sandy areas [10].

The cashew is a perennial plant, with a low branch (branches close to the ground), which presents a varied size [11] According to the size of the plants, the cashew is classified into two types, the common (giant) and the early dwarf [12].

Due to its dispersion, carried out by the colonizers since the 16th century (between 1563 and 1578), the cashew is currently found in various parts of the world, vegetating and producing even 
in ecological conditions considered unsatisfactory, which characterizes it as a plant with great adaptive capacity [13].

The aerial part (crown) of the common cashew can reach up to $20 \mathrm{~m}$ in height, which is why it is also called a giant. However, it is more common for cashew nuts between 8 and $15 \mathrm{~m}$ tall, with a diameter (wingspan) proportional to or greater than the height [14].

According to [15], there is consensus that the inflorescence, the type of flowers (perfect, staminate and anomalous), the number of flowers, the flowering pattern and the sex ratio of the flowers are correlated, to a greater or lesser extent. less measure. to a lesser degree, with the productivity of the cashew. In general, the percentage of fruits formed in relation to the number of perfect flowers produced is considered very low.

From a nutritional point of view, cashews are considered a source of vitamin C, B vitamins and iron, and can be considered a relevant source of antioxidant compounds, which are necessary for human health. Thus, peduncles, when eaten fresh, confer direct benefits to human health [16].

Affirms that the flowering of the cashew occurs preferably during the dry season, in which little cloudiness and high insolation predominate. The author also states that, as the producing regions move away from Ecuador, the flowering gradually becomes later, a fact linked to insolation [17].

The cashew is part of these trees; if the environment is poor, they will grow slowly and bear little fruit, but they will survive. If you plant them with other species that will fertilize the soil and moisten the environment, after a while they will take advantage of new resources (nutrients and moisture in the soil) and will begin to produce a lot of fruit [18].

\section{II.5 INGÁ EDULIS}

Ingá is a pioneer species, belonging to the Mimosácea family, widely used in the afforestation of streets and squares and very suitable for the recovery of riverside forests in rivers, lakes and reservoirs [19].

It blooms during the months of October to January and the fruits ripen from May onwards. Its wood is moderately heavy, soft, hardly durable, and moderately mechanically resistant. The wood is used for drawer work, charcoal and firewood. Its fruits are consumed and commercialized by the populations of the Amazon region [20].

According to [21], its wood is recommended for the manufacture of fine furniture, making artifacts for civil construction, poles, posts, sleepers and others. Tannin is obtained from the bark, which is widely used in leather tanning. It is also a honey plant 16 and with potential for use in urban forestry and landscaping, mainly squares and public parks.

According to [22], species of the genus Ingá should not be lacking in riparian forest restoration programs, since they are typical species of the soils of the lowlands of the Atlantic Forest and support places with floods.

Characterizes the mechanical fixation of the vegetation under the Amazonian soil in which he emphasizes that it is only in the soil where growth occurs and does not come from the soil, nourishing itself through a closed circulation, in contrast to land soils. Lowlands are extremely fertile, especially for crops such as corn and beans, due to the extensions of the pre-Andean region, constituted and maintained by the intermittent transport of eroded soils, which is why they are classified as infertile soils [23].

\section{II.6 FLEXUOSA MAURITIA}

Buriti is a species of palm of Amazonian origin, also known by the names of buriti-do-brejo, carandá-guaáu, carandaí-guaáu, coco-buriti, itá, palm-dos-brejos, buritizeiro, meriti, miriti, muriti, muritim, muruti. [24].

This species of palm is found in various plant formations, being common in flooded, sandy soils, such as igapó, ribera and igarapés, tolerating remaining with part of the trunk submerged in water for long periods [25].

\section{II.7 EUTERPE OLERACEA}

According to [26], the plantation of açaí in rainfed areas represents an excellent alternative for the recovery of deforested areas, as well as to reduce the pressure on the alluvial plain ecosystem, much more fragile, avoiding its transformation into homogeneous forests of this palm tree.

The açaizeiro grows well in these ecosystems, however, the different patterns of structural adaptability allow for full reproductive development in highland areas [27].

In floodplain areas, native-managed açaizais are concentrated in the estuary of the Tocantins, Pará and Amazon rivers. In the municipality of Igarapé-Miri, Pará, this practice began in the early second half of the 1990s, in areas subject to tidal flooding [28].

The flood consists of a gradual increase in the water level, which takes a period of 6 hours and 12 minutes to reach its maximum level, called "high tide". At this point, it stays for about 7 minutes until reflux begins. The ebb is, therefore, the lowering of the water level, also for an approximate time of 6 hours and 12 minutes, until it reaches its minimum level, the "low tide". At this time, in the same way, the level stabilizes for another 7 minutes until the flow begins again [29].

The availability of water in the soil influences the growth, distribution and survival of plants. Under natural conditions, plants that live in humid places, such as açaí, are naturally subject to a moderate water deficit on certain occasions. The ability to tolerate moderate stress is very important for the propagation of the species in environments other than its natural habitat [30].

Palm trees are adapted to different environments such as lowlands, igapó and firm ground, due to their ability to allocate resources to leaves and roots. The efficiency of the leaves to capture light energy, the ability to convert that energy into carbohydrates, as well as its transport and metabolism in the different parts of the plants are factors that influence the growth and survival of palm trees when they grow in adverse places [31].

The objective of recovering degraded areas is the restoration of an ecosystem, by planting native species adapted to the conditions of the natural environment [32].

A fundamental aspect in this process is the choice of the species, where the adaptability of the species to local environmental conditions, the attraction of fauna, the rapid growth and the large deposition of garbage must be considered [33].

The buriti is a perennial plant that is found in swampy or permanently humid areas, it serves as a source of food, shelter and breeding ground for various elements of the fauna [34]. These characteristics indicate great potential for wetland recovery.

Studied the survival and initial growth of seedlings of Euterpe edulis Mart. transplanted to clearings and understory in a seasonal semi-deciduous forest found higher survival in clearings $(53 \%)$ and lower in shaded understory $(20 \%)$ [35].

States that shallow areas are usually relatively flat surfaces within which the igarapé is located. The soil is sandy because, over 
a long period of time, the water in the local watershed slowly removes the clay it contains. The water table is near the surface and blooms in the stream, however the soil is not completely soaked all the time, especially in the areas closest to the slope [36].

\section{II.8 GREENHOUSE GASES}

According to [37], greenhouse gases form a kind of layer that surrounds the Earth with gaseous constituents, through which solar radiation enters and part of the heat generated is eliminated into space in the form of infrared radiation. But today much of this infrared radiation is not capable of passing through the GHG layer, which raises great concern, since some of these gases remain in the atmosphere for years, retaining the radiation that should be emitted into space, becoming responsible for climate change [38].

The industrial revolution was a great benefit for the population, but pollution grew along with the emission of polluting gases that contribute to global warming, the main ones being carbon dioxide and monoxide [39]. The increase in carbon dioxide, consequently the cause of global warming, is mainly produced by anthropogenic activities, such as deforestation of forests and burning of fossil fuels, power generation, among others [40].

Deforestation emits carbon dioxide $\left(\mathrm{CO}_{2}\right)$ and other greenhouse gases. Some of the $\mathrm{CO}$ rea is then reabsorbed through the regrowth of secondary forests in deforested areas, but the other greenhouse gases, such as methane $\left(\mathrm{CH}_{4}\right)$ and nitrous oxide $\left(\mathrm{N}_{2} \mathrm{O}\right)$, are not. The amount of carbon absorbed as $\mathrm{CO}_{2}$ by regrowth of secondary forests is small compared to the initial emission, because the biomass per hectare of secondary forest is much lower than that of primary forest [41].

\section{II.9 GREENHOUSE EFFECT}

The greenhouse effect is mainly caused by the emission of $\mathrm{CO}_{2}, \mathrm{CH}_{4}, \mathrm{~N}_{2} \mathrm{O}$, chlorofluorocarbons (CFCs) and water vapor. Among them, $\mathrm{CO}_{2}$ is the gas that contributes the most to the greenhouse effect, due to the large amount that is emitted, around $55 \%$ of the total. In turn, the amount of $\mathrm{CH}_{4}$ emitted into the atmosphere is much lower, but its warming potential is 23 times greater than that of $\mathrm{CO}_{2}$. Although the concentrations of $\mathrm{N}_{2} \mathrm{O}$ and $\mathrm{CFC}$ in the atmosphere are even lower, the global warming power of these gases is much greater, being, respectively, about 298 and 6,200 to 7,100 times that of $\mathrm{CO}_{2}$ [42].

The fires that accompany deforestation determine the amounts of gases emitted not only from the part of the biomass that is burned, but also from the part that is not burned. When there is a fire, in addition to the release of carbon dioxide $\left(\mathrm{CO}_{2}\right)$, trace gases such as methane $\left(\mathrm{CH}_{4}\right)$, carbon monoxide $(\mathrm{CO})$ and nitrous oxygen $\left(\mathrm{N}_{2} \mathrm{O}\right)$ are also released. The part of the biomass that is not burned in the initial combustion, which is hot, with flames, will also be oxidized [43].

The concentration of $\mathrm{CO}_{2}$ and other greenhouse gases has increased dramatically since the industrial revolution. Since 1750 , approximately $35 \%$ of anthropogenic $\mathrm{CO}_{2}$ emissions are directly related to changes in land use [44].

According to the [45], forests are the largest reservoirs in the carbon cycle that contain around $80 \%$ of this atom. The vegetables, using their photosynthetic capacity, fix the atmospheric $\mathrm{CO}_{2}$, biosynthesizing in the form of carbohydrates, and finally, depositing themselves on the cell wall, thus carrying out the "sequestration" of carbon.

The greenhouse effect can directly cause the death of the Amazon rainforest, in addition to its probable effect through El Niño. Higher temperature averages require each tree to use more water to perform the same amount of photosynthesis. The greenhouse effect does not occur uniformly on the planet and the Amazon is expected to be one of the places with the highest temperature increases [46].

Estimates indicate that the deforestation rate in the Brazilian Amazon is 1.1 to 2.9 Mha yr-1 [47]. Despite this high rate of deforestation, the Amazon, in Brazil, still has approximately $40 \%$ of the remaining area of tropical forest in the world [48].

\section{II.10 CARBON ABSORPTION}

States that a tree fixes an average of $249.6 \mathrm{~kg}$ of $\mathrm{CO}_{2}$ in 20 years and that in the worst case it can fix up to $140 \mathrm{~kg}$. Transformed into exact numbers, it can be said that a tree can fix between $7 \mathrm{~kg}$ and $12.48 \mathrm{~kg}$ of $\mathrm{CO}_{2}$ per year, according to the author's data [49].

The incentive to reduce $\mathrm{CO}_{2}$ in the atmosphere generates expectations for the dissemination of the Brazilian forestry potential, even so, there is a lack of publications that can demonstrate the potential that SAFs have for agricultural production and the recovery of degraded areas [50].

Carbon sequestration has become a viable alternative in $\mathrm{CO}_{2}$ capture to control the emission of greenhouse gases and reduce the effects of global warming [51].

For [52], a tree in the Atlantic Forest absorbs, on average, $163.14 \mathrm{~kg}$ of $\mathrm{CO}_{2}$ in the first 20 years or $8.15 \mathrm{~kg}$ per year, which shows that after twenty years the same tree can fix more or less carbon.

States that a tree can capture about $15.6 \mathrm{~kg}$ of $\mathrm{CO}_{2}$ per year, during the first 20 years and $4.4 \mathrm{~kg}$ after that period. Data that can be studied later, to have information on carbon fixation after 20 years of life of the tree [53].

For [54] studied the survival and initial growth of seedlings of Euterpe edulis Mart. transplanted to clearings and understory in a semi-deciduous seasonal forest, they found greater survival in clearings $(53 \%)$ and lower in shaded understory (20\%). On the other hand, the evaluation of other families of plants in the recovery of degraded areas is more frequent.

When analyzing a 10-year sowing with species from the Myrtaceae, Fabaceae and Clusiaceae families, in Restinga areas degraded by the intense process of removal of vegetation and soil layers for the extraction of sand until 1997, obtained an annual average growth in height of $14.2 \mathrm{~cm}$, considered low by the authors, attributed to soils poor in nutrients, high incidence of light and strong wind action [55].

\section{METHODOLOGY}

The experimental methodology was implemented following 4 steps:

First step: dissemination of environmental education in schools and traditional and indigenous communities around the basin, through conferences, discussion and group work, joint efforts, debate, reflection, imitation and exploration of the local environment. The actions also included theater activities, videos, posters made by children, puppets, sweepers of joy, ending with the creation of an environmental brochure, prepared with the active participation of the community.

The dissemination of environmental education with community members and permit holders in the watershed allows them to be committed to the environment. The talks and activities carried out demonstrated the real importance of planting and reforesting degraded areas, as well as contributing to a more pleasant environment, helping to minimize the contamination of the ozone layer. 
Second step The search for a bibliographic review, consultations of dissertations, theses, scientific articles and books began, with the aim of identifying the level of depth of the information generated on the study area. The acquisition and collection of pre-existing data available in analog and digital media was carried out, such as: satellite images, topographic maps, preexisting maps, among others.

Third step The collection of data and images was carried out in the period from 2015 to 2019, always in the rainy and dry seasons of the region, more precisely in the months of March to August. It was established as parameters for the mortality rate $20 \%$, a percentage considered satisfactory for the continuity of the project, considering the adversities of the region and the planting site.

Finally, to evaluate the percentage of mortality of the species, 500 seedlings of Euterpe Oleracea, 500 of Anacardium Ocidentale, 500 of Ingá Edulis and 500 of Mauritia Flexuosa, approximately 50 to $60 \mathrm{~cm}$ tall and at six months of age, were selected.

For the data on the probability of carbon fixation of species in 20 years, previous studies with information on the amount of carbon absorbed by a tree per year and its projection to 20 years were taken into account, obtaining variable indices in the literature that vary from $7.1 \mathrm{~kg}$ to $15.6 \mathrm{~kg}$ per year.

The data used took into account the results of the analyzes from the period 2015 to 2019, establishing a grand total for the calculations of the percentage of mortality, survival, highlighting the statistical probability of the contribution in the fixation of $\mathrm{CO}_{2}$, in 20 years.

The worksheets used to calculate the data were from Excel with the action stat tool, establishing parameters and projections with the data obtained in the consulted references, where the lowest fixation index considered was $7.1 \mathrm{~kg}$ of $\mathrm{CO}_{2}$ per year and $15.6 \mathrm{~kg}$ as the fixation index being the highest.

For the records, the following were used: Kodak HD Stills camera, Digital IS and then MOTOROLA ONE cell phone, dual camera; a GPS, to mark the location of the area; computer and printer, for storage and printing of research.

The work was carried out with data collected in the field between 2015 and 2019, in the months of March and August, periods of rain and drought respectively in the region. 2000 seedlings of 4 species of fruit trees were selected for planting in the degraded area. As previously described, the selected species are Anacardium Ocidentale (cashew), Ingá Edulis, Ingá açu o zapatilla (ingá), Mauritia Flexuosa (Miriti or Buriti) and Euterpe Oleracea (Açaí), with 500 seedlings of each species.

Table 1 shows the mortality data of the species during the monitoring and study of the data in the period 2015-2019.

Table 1: Seasonal results of species mortality in the flood.

\begin{tabular}{|c|c|c|c|c|c|}
\hline Species & $\begin{array}{c}\mathbf{2 0 1 5} \\
\text { (uno) }\end{array}$ & $\begin{array}{c}\mathbf{2 0 1 6} \\
\text { (uno) }\end{array}$ & $\begin{array}{c}\mathbf{2 0 1 7} \\
\text { (uno) }\end{array}$ & $\begin{array}{c}\mathbf{2 0 1 8} \\
\text { (uno) }\end{array}$ & $\mathbf{2 0 1 9}$ (uno) \\
\hline Cashew & 0 & 0 & 0 & 0 & 0 \\
\hline Ingá & 5 & 6 & 6 & 5 & 5 \\
\hline Buriti & 8 & 6 & 5 & 7 & 6 \\
\hline Açai & 8 & 6 & 5 & 5 & 5 \\
\hline
\end{tabular}

Source: Author, (2020).

Table 1 shows that the Buriti and AAI are those with a mortality rate higher in relation to the ingá and cashews. The survey took place in March of each year, a period of still heavy rain in the region.

\begin{tabular}{|c|c|c|c|c|c|}
\hline Species & $\begin{array}{c}\mathbf{2 0 1 5} \\
\text { (uno) }\end{array}$ & $\mathbf{2 0 1 6}$ (uno) & $\begin{array}{c}\mathbf{2 0 1 7} \\
\text { (uno) }\end{array}$ & $\begin{array}{c}\mathbf{2 0 1 8} \\
\text { (uno) }\end{array}$ & $\mathbf{2 0 1 9}$ (uno) \\
\hline Cashew & 0 & 0 & 0 & 0 & 0 \\
\hline Ingá & 10 & 9 & 7 & 7 & 5 \\
\hline Buriti & 10 & 10 & 10 & 7 & 7 \\
\hline Açai & 8 & 8 & 9 & 5 & 5 \\
\hline \multicolumn{7}{c}{ Source: Author, (2020). }
\end{tabular}

Table 2 shows the mortality data of the species in the dry season of the region. The survey took place in August of each year, the month considered the warmest in the region. It is observed that the mortality rate is higher in relation to the rainy season.

Table 3 shows the overall number of dead seedlings of each species from 2015 to 2019 , as well as the amount of survival, where from this demonstration, all carbon fixation calculations were made in $\mathrm{kg}$ of $\mathrm{CO}$.

Table 3: Survival and overall mortality results from 2015 to 2019

\begin{tabular}{|c|c|c|c|}
\hline Species & $\begin{array}{c}\text { Quantity } \\
\text { Muds(un) }\end{array}$ & Surviving (un) & $\begin{array}{c}\text { Dead } \\
\text { Muds(un) }\end{array}$ \\
\hline Cashew & 500 & 500 & 0 \\
\hline Ingá & 500 & 435 & 65 \\
\hline Buriti & 500 & 424 & 76 \\
\hline Açai & 500 & 436 & 64 \\
\hline
\end{tabular}

Source: Author (2020).

Table 3 shows the data on the real number of mortality and survival of the species, where the cashew nut presented zero mortality, remaining with the 500 planted seedlings. Ingá had 435 live seedlings and 65 dead ones. The buriti had 424 live seedlings and 76 dead and the açaí had 436 live seedlings and 64 dead ones.

Table 4 shows the calculation of the mortality and survival percentages of the species, Excel software was used to obtain the percentages, taking into account 500 planted seedlings.

Table 4: Calculation of the percentage of mortality and survival.

\begin{tabular}{|c|c|c|c|c|}
\hline Species & $\begin{array}{c}\text { Initial } \\
\text { Quantity(un) }\end{array}$ & $\begin{array}{c}\text { Mortality } \\
\%\end{array}$ & $\begin{array}{c}\text { Survival } \\
\%\end{array}$ & $\begin{array}{c}\text { Amount. } \\
\text { Finaly (uno) }\end{array}$ \\
\hline Cashew & 500 & $0,00 \%$ & $100 \%$ & 500 \\
\hline Ingá & 500 & $13,00 \%$ & $87,00 \%$ & 435 \\
\hline Buriti & 500 & $15,20 \%$ & $84,80 \%$ & 424 \\
\hline Açai & 500 & $12,80 \%$ & $87,20 \%$ & 436 \\
\hline
\end{tabular}

Source: Author, (2020).

The result presented took into account the data obtained in May and August of each year, with a final sum of the number of seedlings that died and those that survived. It was observed that the highest mortality rate occurred in the hottest periods and few rains, where there is a reduction in rainfall.

Survival and mortality rates are different when analyzed in the rainy periods (high rainfall) and in the dry season (low rainfall), where plants are the ones that suffer the most due to little rainfall.

The mortality rate in the rainy season is not higher than $5 \%$ of the planted seedlings, so the replacements of the dead occur in this period of high rainfall, which facilitates the survival and development of the species.

Even in the dry season, cashew scans can survive with high rates, its power to adapt to adversity makes it the most widely used species in reforestation in the area. In addition to contributing to the fixation of carbon, it also contributes to the feeding of its fruit for fauna and man.

IV. RESULTS

Table 2: Results of mortality in the dry season. 
Figure 1 shows the percentages of mortality and survival of the species.

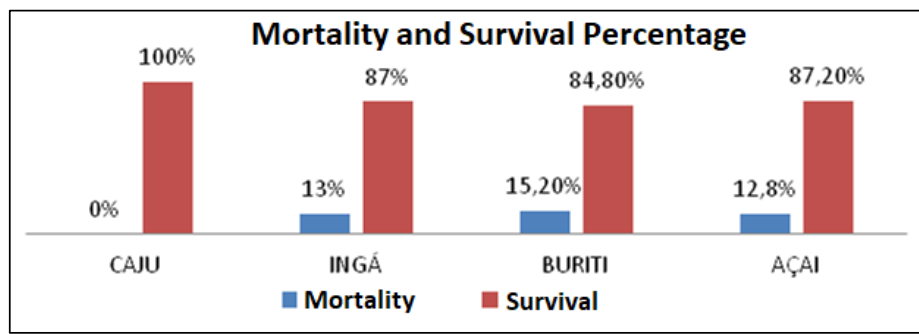

Figure 1: percentage of mortality and survival. Source: Author, (2020).

\section{IV.1 PROBABILITY OF CARBON FIXATION OF THE SPECIES IN 20 YEARS}

The calculations were made in the Excel spreadsheet, through the Stock Statistics tool, in a simple and objective way. The calculation of the $\mathrm{CO}$ fixation at $7.1 \mathrm{~kg}$ is considered the lowest fixation index per year and later at $15.6 \mathrm{~kg}$, considered the highest fixation index found in the theoretical framework.

With the use of the data obtained in the literature, a probability of carbon fixation of the species was made, which varies according to the quantity and the adopted index. Therefore, the amount of carbon fixation is presented by species, by year and in 20 years.

The tables and graphic figures were prepared taking into account the carbon fixation values found in the literature. Calculations can be performed using formulas and results of laboratory research that identify how much each one changes and fixes the carbon species, however, one of the objectives of the research is to analyze and quantify the mortality and survival rate of four species planted in the Tarum-AU Watershed -BHT and carbon fixation in 20 years, for which we chose to use the bibliographic data, considering $7.1 \mathrm{~kg}$ as the lowest index and 15.6 $\mathrm{kg}$ as the highest.

A variation in the carbon fixation index by the age of the plants was not found in the literature, which is found are authors who report the experiences of the plants after 20 years, where the data found showed lower absorption results to those reached in the first 20 years. Table 5 presents data related to the estimation of carbon fixation of the analyzed species, taking into account the lowest fixation index per year, using $7.1 \mathrm{~kg}$ of $\mathrm{CO}$.

Table 5: Estimated carbon fixation for 20 years with an index of $7.1 \mathrm{~kg}$ of $\mathrm{CO}_{2}$.

\begin{tabular}{|c|c|c|c|c|}
\hline Species & $\begin{array}{c}\text { Planted } \\
\text { (un) }\end{array}$ & $\begin{array}{c}\text { Survivors } \\
\text { (un) }\end{array}$ & $\begin{array}{c}\mathbf{C O}_{2} / \mathbf{k g} \\
\text { (years) }\end{array}$ & $\begin{array}{c}\mathbf{C O}_{2} / \mathbf{k g} \\
(\mathbf{2 0} \text { years) }\end{array}$ \\
\hline Cashew & 500 & 500 & 3550,0 & 71000 \\
\hline Ingá & 500 & 435 & 3088,5 & 61770 \\
\hline Buriti & 500 & 424 & 3010,4 & 60208 \\
\hline Acai & 500 & 436 & 3095,6 & 61912 \\
\hline \multicolumn{5}{|c}{ Source: Author, (2020). }
\end{tabular}

Table 5 shows the amount of $\mathrm{CO}$ that the number of surviving trees in the period 2015-2019 can absorb per year and in 20 years of life.

To calculate carbon fixation, the number of surviving plants of the species was multiplied by the index of $7.1 \mathrm{~kg}$ of $\mathrm{CO}_{2}$, the annual estimate of each one is obtained, then multiplied by 20 years, taking into account that the variation is constant in period.
Equation 1 was used to calculate cashew carbon fixation per year.

$$
\begin{gathered}
\text { FIX }=\mathrm{S} \times \mathrm{B} \\
500 \times 7,1 \\
\text { FIX /ano }=3.550 \mathrm{~kg} \mathrm{de} \mathrm{CO}_{2}
\end{gathered}
$$

The 500 cashew plants fix a total of $3,550 \mathrm{~kg}$ of $\mathrm{CO}$ per year, if we take into account the constant variation in mortality during the absorption period. The 500 cashew plants were considered because there was no mortality of the species during the period of the research work.

To calculate the fixation of the species in 20 years still with the lowest absorption rate of $7.1 \mathrm{~kg}$ per year, equation 2 is used.

$$
\text { FIX/20 - FIX } x \text { Time }
$$

Calculation of the $\mathrm{CO}_{2}$ fixation estimate for cashew nut species, using equation 2 .

$$
\begin{gathered}
\text { FIX/20 -FIX /year x } 20 \text { years } \\
\text { FIX/20 x } 3.550 \times 20 \\
\text { FIX/20 - } 71.000 \mathrm{~kg} \mathrm{de} \mathrm{CO}_{2}
\end{gathered}
$$

The cashew can absorb $71,000 \mathrm{~kg}$ of $\mathrm{CO}$ in 20 years. It can be concluded that the 500 cashew seedlings establish between $3,550 \mathrm{~kg}$ of $\mathrm{CO}$ per year and 71,000 kg of CO in 20 years. It should be noted that despite the fact that a considerable number of $\mathrm{kg}$ of $\mathrm{C} 0$ is absorbed, it is necessary that more seedlings are planted, that people are aware that the standing tree is important for the conservation of the climate.

To calculate the carbon fixation of the other species, the two equations 1 and 2, respectively, were used, obtaining the following result for Ingá in the year:

$$
\mathrm{FIX}=435 \times 7,1
$$

$$
F I X=3.089 \mathrm{~kg} \text { de } \mathrm{CO}_{2} \mathrm{p} / \text { year } \text {. }
$$

For 20 years you get:

$$
\text { FIX/20=3.089 } \times 20
$$

$$
\mathrm{FIX} / 20=61.770 \mathrm{~kg} \text { de } \mathrm{CO}_{2} \text { em } 20 \text { years }
$$

The 435 surviving plants of Ingá were considered in the period from 2015 to 2019 , resulting in $3,089 \mathrm{~kg}$ of CO per year and $61,770 \mathrm{~kg}$ in 20 years, so it can be said that the variation in carbon fixation of Ingá ranges between $3,089 \mathrm{~kg}$ and $61,770 \mathrm{~kg}$ of $\mathrm{CO}_{2}$.

Buriti's calculation per year obtains:

$$
F I X=424 \times 7,1
$$

$$
3.010 \mathrm{~kg} \mathrm{CO}_{2} \mathrm{p} / \text { year }
$$

For 20 years of Buriti

$$
\begin{aligned}
& F I X / 20=3.010 \quad x 20 \\
& 60.208 \mathrm{~kg} \mathrm{CO}_{2} \text { em } 20 \text { years }
\end{aligned}
$$


For Buriti's calculations, the 424 surviving plants were considered, which can absorb $3,010 \mathrm{~kg}$ of $\mathrm{CO}_{2}$ per year and are estimated to absorb $60,208 \mathrm{~kg}$ of $\mathrm{CO}$ in 20 years.

For the calculation of $\mathrm{CO}$ fixation of acai berries, the 436 surviving plants were considered from 2015 to 2019.

By replacing the data in equations 1 and 2, you get for one year:

$$
\begin{aligned}
& F I X=436 \times 7,1 \\
& 3.095 \mathrm{~kg} p / \text { year }
\end{aligned}
$$

\section{$3.095 \mathrm{kgp} /$ year}

Calculation of 20 years, you get

$F I X / 20=3.095 \mathrm{~kg} \times 20$

\section{$61.912 \mathrm{~kg} \mathrm{em} 20$ years}

Taking into account the 436 açaí plants, it can be said that they can absorb 3,095 $\mathrm{kg}$ of CO per year and can absorb $61,912 \mathrm{~kg}$ of $\mathrm{CO}$ in 20 years.

Taking into account that the research worked with 500 seedlings of each species, 2000 plants were analyzed in general, however, only 1795 survived in the period from 2015 to 2019. The calculations were made for the number of survivors in equations 3 .is, with the lowest fixation index by plant $(7.1 \mathrm{~kg})$ of $\mathrm{CO}_{2}$, per year and in 20 years, the results obtained:

Carbon fixation of the 1795 plants with an index of $7.1 \mathrm{~kg}$ of $\mathrm{CO}_{2}$ per year.

$$
F I X=1795 \times 7,1
$$

$$
12.744 \mathrm{~kg} \mathrm{CO} \text { years }
$$

Calculation of fixation in 20 years

$$
F I X / 20=12.744 \times 20
$$

\section{$254.890 \mathrm{~kg}$ em 20 years}

The results showed that the 1,795 surviving trees can absorb $12,744 \mathrm{~kg}$ of CO per year with a probability of fixing up to 254,890 $\mathrm{kg}$ in 20 years, taking into account the lowest fixing index.

Figure 2 shows the result of fixation per year for each species, taking into account the $7.1 \mathrm{~kg} \mathrm{CO}$ index and the probability of fixation in 20 years. Through the graph it is possible to analyze the results and conclude that the species contributes to the minimization of environmental impacts through the absorption of CO.

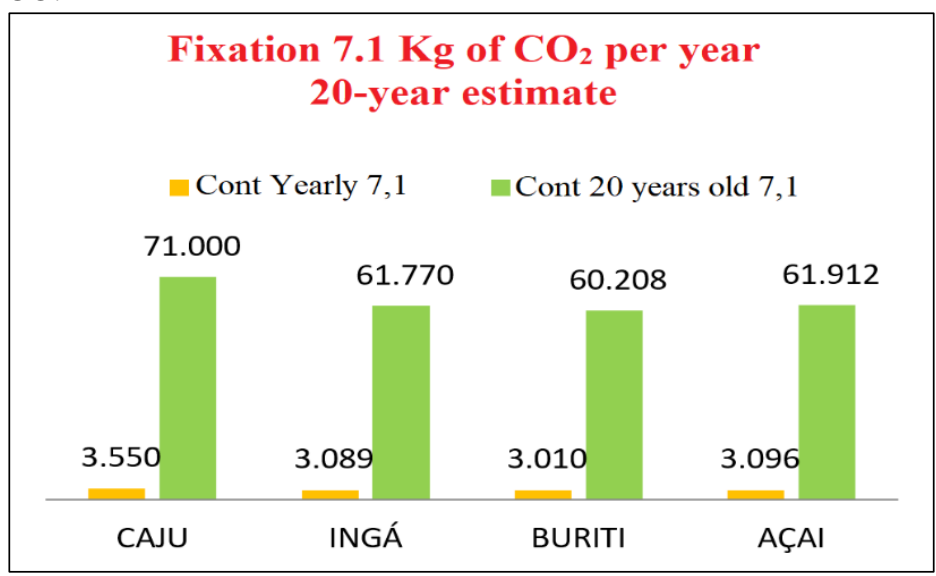

Figure 2: Carbon fixation with $7.1 \mathrm{~kg}$. Source: Author, (2020).
Table 6 presents the data on the CO fixation of the species, estimated for 20 years, using the highest index found in the consulted bibliographies. In this case, each tree absorbs $15.6 \mathrm{~kg}$ of $\mathrm{CO}$ per year.

Table 6: Carbon fixation with an index of 15.6 per year.

\begin{tabular}{|c|c|c|c|c|}
\hline Species & Planted & Survivors & $\mathbf{C O}_{2} /$ years & $\begin{array}{c}\mathbf{C O}_{2} /(\mathbf{2 0} \\
\text { years })\end{array}$ \\
\hline Cashew & 500 & 500 & 7800 & 156000 \\
\hline Ingá & 500 & 435 & 6786 & 135720 \\
\hline Buriti & 500 & 424 & 6614,4 & 132288 \\
\hline Açai & 500 & 436 & 6801,6 & 136032 \\
\hline \multicolumn{5}{|c}{ Source: Author, (2020). }
\end{tabular}

To obtain the results, we consider the number of surviving plants from 2015 to 2019, replacing in equations 1 and 2, changing the literature index to $15.6 \mathrm{~kg}$ of CO per year.

To obtain the cashew results, equations 1 and 2 were used.

$$
\begin{gathered}
F I X=500 \times 15,6 \\
F I X=7.800 \mathrm{~kg} \text { year }
\end{gathered}
$$

Substitution in equation 2

$$
F I X / 20=7.800 \times 20
$$

FIX/20o $156.000 \mathrm{~kg}$

To calculate ingá fixation, the following were used and obtained as results:

$$
F I X=435 \times 15,6
$$

$6.786 \mathrm{~kg} \mathrm{CO} \mathrm{O}^{2}$ por year

For the calculation of 20 years

$$
\begin{aligned}
& F I X / 20=6.786 \times 20 \\
& 135.720 \mathrm{~kg} \mathrm{CO}_{2} \text { in } 20 \text { years }
\end{aligned}
$$

For the Buriti calculation, you get:

$F I X=424 \times 15,6$

$6.614 \mathrm{~kg}$ de $\mathrm{CO}_{2} /$ years

Probability for 20 years

$F I X / 20=6.614 \mathrm{~kg} \times 20$

$32.288 \mathrm{~kg}$ de $\mathrm{CO}_{2}$ em 20 years

Finally, calculation of carbon fixation of the acai berry, where the results are obtained:

$$
F I X=436 \times 15,6
$$

\section{$6.801 \mathrm{~kg} \mathrm{de} \mathrm{CO}_{2} \mathrm{p} /$ year}

Probability of carbon fixation in 20 years

$$
F I X / 20=6.801 \mathrm{~kg} \times 20
$$

$136.032 \mathrm{~kg}$ de $\mathrm{CO}_{2}$ em 20 years 
Carbon fixation of surviving plants from 1795 using the literature index of $15.6 \mathrm{~kg} \mathrm{CO}_{2}$ per year.

\section{FIX 1795 X 15,6}

$$
28.002 \mathrm{~kg} \text { CO year }
$$

Fixing calculation at 20 years

FIX20 X 28.002 X 20

$$
560.040 \mathrm{~kg} \text { de CO } 20 \text { years }
$$

The result presented in the calculation of carbon fixation in 20 years, taking into account the highest index in the Literature of 15.6, showed that surviving trees from 1795 can absorb $28,002 \mathrm{~kg}$ of CO per year with a probability of absorbing $560,040 \mathrm{~kg}$ of CO in 20 years. A significant number in the fight against environmental degradation

Figure 3 shows the result of the projection of carbon fixation of the species, taking into account the $\mathrm{CO}_{2}$ index of $15.6 \mathrm{~kg}$ that each one absorbs per year, using in the calculations the number of survivors in the period 2015-2019.

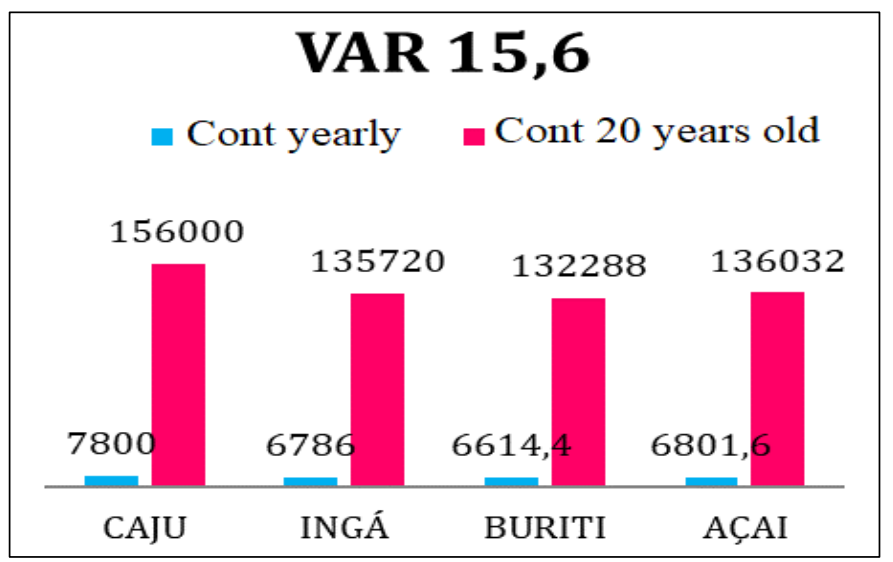

Figure 3: Carbon fixation with $15.6 \mathrm{~kg}$ CO per year.

Source: Author, (2020).

To analyze the estimate, we consider the study of mortality and survival of the species, obtained between 2015 and 2019. Survey carried out in March and August of each year, considering the initial planting of 500 seedlings of each species.

The carbon fixation of each one was considered with $7.1 \mathrm{~kg}$ and $15.6 \mathrm{~kg}$ per year and the probability of fixation in 20 years, both individually and collectively. You can tell how much a fixed plant can repair a fixed plant and how many 100, 200 or even the total number of survivors can fix carbon, removing greenhouse gases from the atmosphere.

In addition to the species used for reforestation and recovery of the degraded area, they still contribute to the cleaner environment. They conserve the igarapés that are part of the BHT, providing a quality environment for people and for existing fauna.

The planted species have the capacity for natural dissemination, due to seeds that proliferate more rapidly in the rainy season, not failing to proliferate also in a dry season, even if this proliferation is slower.

Figure 4 shows the carbon fixation data of the species in one and 20 years, considering the lowest and highest index in the literature of 7.1 and $15.6 \mathrm{~kg}$ of $\mathrm{CO}_{2}$.
Carbon Fixation with 7.1 and $15.6 \mathrm{~kg}$ of $\mathrm{CO}_{2}$
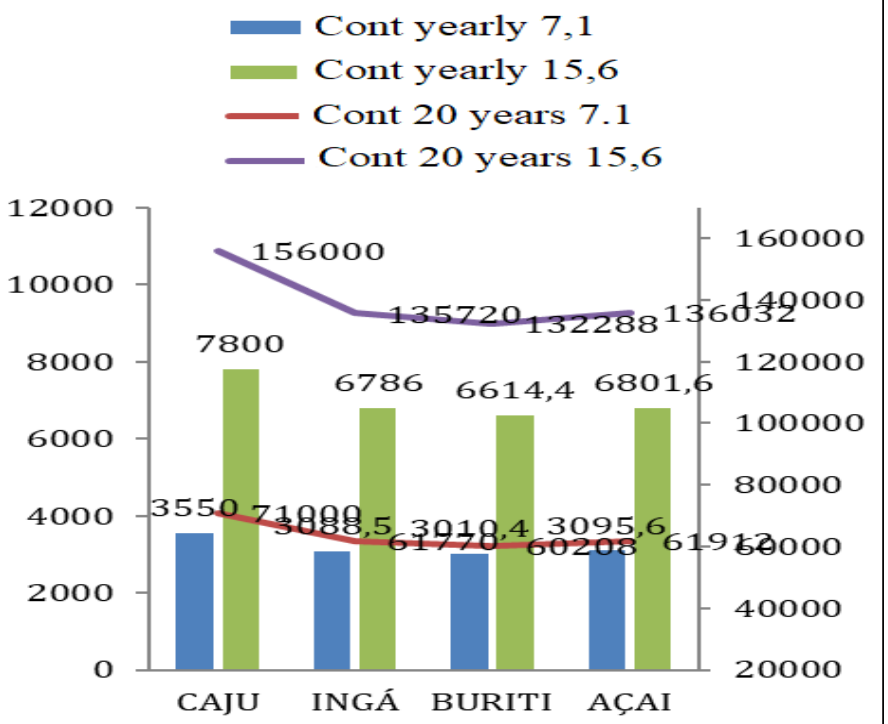

Figure 4: fixation comparison, $\mathrm{CO}_{2} 7.1 \mathrm{~kg}$ and $15.6 \mathrm{~kg}$. Source: Author, (2020).

\section{CONCLUSIONS}

To conclude the investigated data and with the objectives proposed in the research work, a synthesis of the results obtained in the comparison of the carbon fixation index with $7.1 \mathrm{~kg}$ of $\mathrm{CO}$ and $15.6 \mathrm{~kg}$ per species is carried out. In the research, we used data from 4 species selected for the recovery and reforestation of the degraded area in the BHT, and 500 trees from each were analyzed for mortality and survival.

It is perceived that in the course of research work and with data obtained in situ and through the literature, these species can successfully absorb and fix carbon, reducing and minimizing greenhouse gases. Regarding the general objective, it can be concluded that the investigation of the mortality and survival rate of the species was answered clearly and objectively, taking into account the data obtained in 2019 , in addition to presenting the estimates of carbon fixation in 20 years.

Regarding the specific objectives, the survival and mortality analysis showed the cashew with the highest survival rate and the contribution to carbon fixation in 20 years. He mapped the data and disseminated environmental education in communities and schools adjacent to the deforested area.

Although the bibliographic research knew the an assistants of the research work, the lack of methods and studies on carbon fixation by species was identified. It was also verified that among the studies and bibliographies investigated, less than $5 \%$ bring on the subject, specifically, and more studies are needed focused on the topic, and therefore we can have more content smoother for what the research. It can be concluded that the reforestation and recovery of the degraded area of the BHT, using fruit species, objects of research, contribute to improving the quality of life of people and minimize the impacts of greenhouse gases.

Due to the broad scope of the topic addressed in this study, here are some suggestions for the continuation of this research work.

i) New research on species fixation after 20 years;

ii) $\rightarrow$ the survival rate from the first year;

iii) $\rightarrow$ Carbon Neutralization;

iv) $\rightarrow$ Diffusion of seeds through fauna;

v) $\rightarrow$ Carbon Credit; 
vi) $\rightarrow$ The Fauna and Flora of BHT and their contribution to the preservation process of degraded areas.

\section{AUTHOR'S CONTRIBUTION}

Conceptualization: Eliana da Conceição Rodrigues Veras.

Methodology: Eliana da Conceição Rodrigues Veras.

Investigation: Eliana da Conceição Rodrigues Veras.

Discussion of results: Eliana da Conceição Rodrigues Veras.

Writing - Original Draft: Eliana da Conceição Rodrigues Veras.

Writing - Review and Editing: Eliana da Conceição Rodrigues

Veras.

Resources: Eliana da Conceição Rodrigues Veras.

Supervision: Eliana da Conceição Rodrigues Veras.

Approval of the final text: Eliana da Conceição Rodrigues Veras.

\section{REFERENCES}

[1] Aduan, R. A.; Vilela, M. de F.; Klink, C. A. Ciclagem de carbono em ecossistemas terrestres: o caso do Cerrado brasileiro. Ministério da agricultura, pecuária e abastecimento, documentos 105, ISS 1517 - 5111. EMBRAPA, 2003.

[2] Amarante, Zoraide. A Gestão Ambiental Municipal e o "Desenvolvimento Sócio Espacial Sustentável" - A Experiência de Campinas/S.P. 1988. Disponível em: http://www.race.nuca.ie.ufrj.br/. Acesso em 28 de dezembro de 2019.

[3] Aguiar, F.E.O. 1995. As alterações climáticas em Manaus no Século XX. Dissertação de Mestrado - Universidade Federal do Rio de Janeiro / PPGG, 183 pp.

[4] Albuquerque, B. P. de. As relações entre o homem e a natureza e a crise sócioambiental. Rio de Janeiro, RJ. Escola Politécnica de Saúde Joaquim Venâncio: Fundação Oswaldo Cruz (Fiocruz), 2007. Disponível em: Acesso em: 13 Jan 2020.

[5] Abreu, I. de S.; Gonçalves, L. C. S. O direito fundamental ao meio ambiente ecologicamente equilibrado e a educação ambiental no Brasil. Derecho y Cambio Social. N. 5822, 2013. Disponível em: Acesso em: 10 Jan 2020.

[6] Almeida, D.S. Modelos de recuperação ambiental. In: Recuperação ambiental da Mata Atlântica [online].3rd ed. rev. and enl. Ilhéus, BA: Editus, 2016, pp. 100137. ISBN 978-85-7455-440-2. Available from SciELO Books. Acesso em 28 de dezembro de 2019.

[7] Andreae, M.“Smoking rain clouds over the Amazon”, Science, 303, 1337- 1342. 2004.

[8] Artaxo, P.; Gatti, L.V.; Cordova, A.M.; Longo, K.M.; Freitas, S.R.; Lara, L.L.; Pauliquevis, T.M.; Procopio, A.S.; Rizzo, L.V.. Química atmosférica na Amazônia: a floresta e as emissões de queimadas controlando a composição da atmosfera amazônica. Acta amazônica, v. 35, n. 2, p. 185- 196, 2005.

[9] Backer, P. Gestão ambiental. 1. ed. Rio de Janeiro: Qualitymark, 1995.

[10] Barbieri, José Carlos. Gestão ambiental empresarial: conceitos, modelos e instrumentos. São Paulo; Saraiva; 2004.

[11] Barros, L. M. Botânica, origem e distribuição geográfica. In.: ARaújo, J. P. P.; Silva, V. V. (Org.). Cajucultura: modernas técnicas de produção. Fortaleza: EMBRAPA-CNPCa, 1995. p. 55-71.

[12] Barros, Talita Delgrossi; Jardine. José Gilberto. Árvore do Conhecimento. Agência Embrapa de Informação Tecnológica. www.agencia.cnptia.embrapa.br. Acessado em 17 de dezembro de 2019.

[13] Bentes Junior, Jeú Linhares. Utilização do sig e sensoriamento remoto como subsídio para elaboração do zoneamento ambiental da bacia hidrográfica do tarumã. 2009. Dissertação de Mestrado- Curso em Ciências do Ambiente e Sustentabilidade na Amazônia - CASA, da Universidade Federal do Amazonas.

[14] Botelho, S. A. et al. Avaliação do crescimento do estrato arbóreo de área degradada revegetada à margem do Rio Grande, na usina hidrelétrica de Camargos, MG. Revista Árvore. V. 31, 2007. Disponível em < http//www.scielo.br/pdf/rarv/v31n1/20.pdf> Acesso em 15 novembro 2018.

[15] BRASIL. Decreto n. 97.632, de 10 de abril de 1989. Dispõe sobre a regulamentação do Artigo $2^{\circ}$, inciso VIII, da Lei n ${ }^{\circ} 6.938$, de 31 de agosto de 1981, e dá outras providências.
[16] BRASIL. Decreto n 16.498 de 02 de abril de 1995. Cria a APA da Margem Esquerda do Rio Negro com 740.757 hectares. Destina-se a proteger e conservar a qualidade ambiental e os sistemas naturais existentes, visando a melhoria da qualidade de vida da população e dá outras providências.

[17] BRASIL. Departamento Nacional de Produção Mineral. Projeto RADAMBRASIL. Folha SA. 20 Manaus: geologia, geomorfologia, pedologia, vegetação e uso potencial da terra. Rio de Janeiro: DNPM, 1978. v. 18

[18] BRASIL. Lei 2.646 de 22 de maio de 2001. ALTERA os limites do Parque Estadual do Rio Negro, Setores Norte e Sul, e das Áreas de Proteção Ambiental, das Margens Esquerda e Direita do Rio Negro,... A Área de Proteção Ambiental da Margem Esquerda do Rio Negro, Setor Tarumã - Açu - Tarumã - Mirim, criada pelo Decreto n.o 16.498, de 2 de abril de 1995, passa a ter 56.793 hectares. Assim, a APA passa a ter um total de 643.215 hectares.

[19] Bonissoni, R.M. et al. A gestão ambiental de uma fábrica de bebida energética por meio da sustentabilidade ambiental. In: CONGRESSO UFSC DE CONTROLADORIA E FINANÇAS. 3., 2009, Florianópolis. Anais.. Florianópolis: Departamento de Ciências Contábeis/UFSC, 2009.

[20] Calbo, Maria Elza Ribeiro e MORAES, José Antônio P. V. de. Efeito da deficiência de água em plantas de Euterpe oleracea (açaí). Revista Brasileira de Botânica, 23(3):225-230, 2000.

[21] Carpanezzi, A. A. et al. Espécies pioneiras para recuperação de áreas degradadas: a observação de laboratórios naturais. In: CONGRESSO FLORESTAL BRASILEIRO, 6, 1990, Campos do Jordão, Anais... São Paulo: SBS, 1990. V.3. p 216-221

[22] Cerri, C.E.P.; Sparovek, G.; Bernoux, M.; Easterling, W.E.; Melillo, J.M. \& Cerri, C.C. Tropical agriculture and global warming: Impacts and mitigation options. Sci. Agric., 64:83-99, $2007 \mathrm{a}$.

[23] Cerri, C.E.P.; Easter, M.; Paustian, K.; Killian, K.; Coleman, K.; Bernoux, M.; Powlson, D.S.; Batjes, N.H.; Milne, E. \& Cerri, C.C. Predicted soil organic carbon stocks and changes in the Brazilian Amazon between 2000 and 2030. Agric. Ecosyst. Environ., 122:58-72, 2007b.

[24] Cláudio, C. F. B. R. Implicações da avaliação de impacto ambiental. Revista ambiente, Munich, v.1, n.3, p. 159-163, 1997.

[25] Chada, S.S.; Campello, E.F.C.; Faria, S.M. Sucessão vegetal em uma encosta reflorestada com leguminosas arbóreas em Angra dos Reis, RJ. Revista Árvore, Viçosa, v. 28, n. 6, p. 801-809, 2004.

[26] Crisóstomo, L. A.; Santos, F. J. S.; Oliveira, V. H.; Van Raij, B.; Bernardi, A. C. C.; Silva, C. A.; Soares, I. Cultivo do cajueiro anão precoce: aspectos fitotécnicos com ênfase na adubação e na 161 Capítulo 3 Aspectos botânicos, fenologia e manejo da cultura do cajueiro irrigação. Fortaleza: Embrapa Agroindústria Tropical, 2003. 8 p. (Embrapa Agroindústria Tropical. Circular Técnica, 08).

[27] Dias, Reinaldo. Gestão ambiental: responsabilidade social e sustentabilidade. São Paulo; Atlas; 2011

[28] Dias, R. Gestão ambiental: Responsabilidade social e sustentabilidade. São Paulo, Atlas, 2006

[29] Durigan, G.; Figliolia, M. B.; Kawabata, M.; Garrido, M. A. O.; Baitello, J. B Sementes e mudas de árvores tropicais. São Paulo: Páginas \& Letras Editora e Gráfica, 2. ed.. 65p. 2002.

[30] Fearnside, Philip M. Fogo e emissão de gases de efeito estufa dos ecossistemas florestais da Amazônia brasileira. Estudos Avançados, v. 16, n. 44, p. 99-123, 2002.

[31] Fearnside, P. M.; Leal Filho, N. Solo e Desenvolvimento na Amazônia-Lições do Projeto Dinâmica Biológica de Fragmentos Florestais. INPA/MCT, 2002.

[32] Fearnside, P.M. Desmatamento na Amazônia brasileira: história, índices e consequências. Megadiversidade, v. 1, n. 1, p. 114-123, 2005.

[33] Fearnside, P.M. Desmatamento na Amazônia: dinâmica, impactos e controle Acta amazônica, v. 36, n. 3, p. 395-400, 2006.

[34] Felfili, J.M.; Ribeiro, J.F.; Fagg, C.W.; Machado, J.W.B. Recuperação de matas de galeria. Planaltina: Embrapa Cerrados, 2000. 45 p. 
[35] Ferreira, L. F. et al. Contabilidade ambiental sistêmica. In: CONGRESSO UFSC DE CONTROLADORIA E FINANÇAS. 2., 2008, Florianópolis. Anais... Florianópolis: Departamento de Ciências Contábeis/UFSC, 2008.

[36] Fidalgo, A.O.; Alcântara, R.P.; Caldiron, G.T. Parâmetros de crescimento na avaliação de uma floresta implantada em uma restinga degradada pela mineração. Revista Brasileira de Biociências, Porto Alegre, v. 7, n. 4, p. 382-386, 2009.

[37] Foley, J.A.; Defries, R.; Asner, G.P.; Barford, C.; Bonan, G.; Carpenter, S.R.; Chapin, F.S.; Coe, M.T.; Daily, G.C.; Gibbs, H.K.; Helkowski, J.H.; Holloway, T.; Howard, E.A.; Kucharik, C.J.; Monfreda, C.; Patz, J.A.; Prentice, I.C.; Ramankutty, N. \& Snyder, P.K. Global consequences of land use. Science, 309:570-574, 2005.

[38] Frota, P. C. E. Clima e fenologia do cajueiro. In: Lima, V. P. M. S. (Org.). A cultura do cajueiro no Nordeste do Brasil. Fortaleza: BNB/ETENE, p. 63-80, 1988.

[39] Frota, P. C. E.; Parente, J. I. G. Clima e fenologia do cajueiro. In: Araújo, J.P.P; Silva, V.V. (Org.). Cajucultura: modernas técnicas de produção. Fortaleza: EMBRAPA-CNPAT, 1995. p. 43-54.

[40] Gasnier, T. R. Apostila de Biomas e Ecossitemas da Amazônia. Ed.1, 2007.

[41] Gonçalves, R. M. G. Aplicação de modelo de revegetação em áreas degradadas, visando à restauração ecológica da microbacia do córrego da Fazenda Itaqui, no município de Santa Gertrudes, SP. Rev. Inst. Flor., São Paulo, v. 17, n. 1, p. 73-95, jun. 2005.

[42] Hemdadez, Manuela Imamura. Benefícios das árvores e seu valor. 2009. www.ecycle.com.br. Acessado em 05 de janeiro de 2020.

[43] IBAMA, Manual de recuperação de areas degraddas pela mineração: técnicas de revegetação. Brasília, IBAMA,1990. 96p.

[44] IPCC [Intergovernmental Panel on Climate Change]. Climate change 2007: The physical Science Basis - Contribution of Working Group I to the Fourth assessment report of the Intergovernmental Panel on Climate Change. Cambridge: University, 2007. 989p. Disponível em: . Acesso em: 17 maio, 2020.

[45] Jezini, J. F. A, Albuquerque, A . R. DA C. Organização Sócio-espacial da Bacia do Igarapé do Tarumã-Açú: Expansão Urbana versus Uso Sustentável da Paisagem. Projeto final PIBIC. Dep. Geografia. Manaus, AM. 45p 2002.

[46] Kageyama, P.; Gandara, F. B. Recuperação das Áreas Ciliares. In: Rodrigues, R.R.; Leitão Filho, H.F. (Ed.). Matas ciliares: conservação e recuperação. São Paulo: Universidade de São Paulo, 2000. p. 249-269.

[47] Kato, O. R.; Shimizu, M. K.; Borges, A. C. M. R.; Azevedo, C. M. B. C.; Oliveira, J. S. L.; Vasconcelos, S. S.; S.Á, T. D. A. Desenvolvimento da produção de frutas em sistemas agroflorestais no estado do Pará. XXII Congresso Brasileiro de Fruticultura. Bento Gonçalves, RS. 2012.

[48] Köppen, W. Climatologia: com un estudio de los climas de la tierra. México: Fondo de Cultura Economica, 1948.

[49] Lacerda, Jeanicolau Simone de, Afinal, quanto carbono uma árvore sequestra. www.oeco.org.br, 2009. Acessado em 05 de janeiro 2020.

[50] Laurance, W.F.; Cochrane, M.A.; Bergen, S.; Fearnside, P.M.; Delamônica, P.; Barber, C.; D'Angelo, S. \& Fernandes. T. The future of Brazilian Amazon. Science, 291:438-439, 2001.

[51] Leal, Georla Cristina Souza de Gois; FARIAS, Maria Sallydelandia Sobral de; ARAUJO, Farias de. O Processo de Industrialização e seus Impactos no Meio Ambiente Urbano. Qualit@s Revista Eletrônica. ISSN v. 7.n.1, p. 1677-4280. 2008.

[52] Lorenzi, H. Árvores brasileiras: manual de identificação e cultivo de plantas arbóreas nativas do Brasil. Nova Odessa: Editora Plantarum, 1992. 281 p.

[53] Lorenzi, H. Árvores brasileiras: manual de identificação e cultivo de plantas arbóreas nativas do Brasil/ Harri Lorenzi. 2. ed. Nova Odessa, SP: Instituto Plantarum, 2002.

[54] Lima, C. J. G. S.; Oliveira, F. A.; Medeiros, J. F. Oliveira, M. K. T.; Almeida Júnior, A. B. Resposta do feijão-caupi a salinidade da água de Irrigação. Revista Verde Agroecologia e Desenvolvimento Sustentável, v. 2, n. 2, p. 79-86, 2007.

[55] Lopes, M.M.A.; Miranda, M.R.A.; Moura, C.F.H.; Enéas Filho, J. Bioactive compounds and total antioxidant capacity of cashew apples (Anacardium occidentale L.) during the ripening of early dwarf cashew clones. Ciência e Agrotecnologia, Lavras, v. 36, n. 3, p.325-332, 2012. 